\title{
Correction to: Michael Gove's war on professional historical expertise: conservative curriculum reform, extreme whig history and the place of imperial heroes in modern multicultural Britain
}

\section{Matthew Watson ${ }^{1}$}

Published online: 10 December 2019

(c) Springer Nature Limited 2019

\section{Correction to: British Politics (2019). https://doi.org/10.1057/s41293-019-00118-3}

The article "Michael Gove's war on professional historical expertise: conservative curriculum reform, extreme whig history and the place of imperial heroes in modern multicultural Britain", written by Matthew Watson was originally published electronically on the publisher's internet portal (currently SpringerLink) on 16 May 2019 without open access.

The copyright of the article changed to (C) The Author(s) 2019, and the article is distributed under the terms of the Creative Commons Attribution 4.0 International License (http://creativecommons.org/licenses/by/4.0/), which permits unrestricted use, distribution and reproduction in any medium, provided you give appropriate credit to the original author(s) and the source, provide a link to the Creative Commons license and indicate if changes were made.

The original article has been updated.

Publisher's Note Springer Nature remains neutral with regard to jurisdictional claims in published maps and institutional affiliations.

The original article can be found online at https://doi.org/10.1057/s41293-019-00118-3.

Matthew Watson

matthew.g.watson@warwick.ac.uk

1 Department of Politics and International Studies, University of Warwick, Coventry CV4 7AL, UK 